\title{
Determinants of Degree of Integration of Turkish Diaspora in Belgium, the \\ Netherlands and Germany
}

\author{
Roya Imani Giglou ${ }^{1}$ \\ roya.imanigiglou@soc.kuleuven.be \\ Leen d'Haenens \\ leen.dhaenens@soc.kuleuven.be \\ Baldwin Van Gorp \\ baldwin.vangorp@soc.kuleuven.be
}

KU Leuven

Institute for Media Studies

Parkstraat 45

B-3000 Leuven

Any correspondence should be sent to first author

\begin{abstract}
This study constructs and tests the building of social capital and integration among Turkish minorities $(n=976)$ residing in three countries with different integration policy realities according to the Migrant Integration Policy Index (MIPEX) for Belgium, the Netherlands, and Germany. Through online and offline surveys the study examines the extent to which bridging and bonding social capital, the dominant language of media use and the socio-demographic characteristics of respondents affect their degree of integration. The results show that the degree of integration increases with a sense of belonging to a faith, length of stay in Europe, exposure to European mainstream media, and through bridging with natives in the host society.
\end{abstract}

\footnotetext{
1 Corresponding author:

Roya Imani Giglou, Faculty of Social Science, Institute for Media Studies, University of Leuven, Parkstraat 45 box 3603, 3000 Leuven, Belgium.

Email: roya.imanigiglou@soc.kuleuven.be
} 
Integration levels decrease, however, with the retention of Turkish citizenship. The degree of integration among the Turkish diaspora varies widely across the three countries under study.

Keywords / Integration/ Social capital / Bridging / Bonding / Social media / Traditional media/ Turkish diaspora / Migrants / Immigrants / Gezi Park movement

\section{Introduction}

Europe is home to a wide range of distinctive populations of varying racial, ethnic, religious, and national foundations, thanks in part to historic and contemporary immigration from other parts of the world (Koopmans et al. 2005). Given such demographics, along with the substantial numbers of migrants moving into Europe each year, questions about how to integrate migrants and other ethnic minorities socially, economically and politically are hotly debated across the continent and beyond (Geddes and Scholten 2016).

Uneven integration of ethnic minorities into receiving societies raises concerns about increasing inequalities (Koopmans 2010), security (Huysmans 2000), terrorism (Lahav and Perliger 2016) and threats to national culture and identity (McLaren 2003). Marginalization experienced by ethnic minorities can result in further isolation. Immigrant groups may respond by building and strengthening relationships from within their communities (bonding) at the expense of building new relationships with members of the receiving society (bridging) with critical economic and labor market effects (Lancee 2010). In its role as a receiving society, Europe is faced with pressing questions: What enables full integration? What blocks it? What explains variation in integration within and across ethnic minorities and across Europe?

This study aims to address some of these questions by providing a systematic measurement of the degree of integration of the Turkish diaspora living in three European countries: Belgium, the Netherlands and Germany. The Turkish diaspora represents one of the largest groups of non-EU residents in western Europe. While accurate estimates of the Turkish 
diaspora population are difficult to achieve, the Turkish Ministry of Foreign Affairs (2017) estimates that more than six million Turks live abroad, 5.5 million of whom live in western European countries. For the three countries in this study, the Turkish diaspora represents the largest portion of non-EU residents within their borders and their degree of integration has important social and economic consequences for these countries and beyond.

In spite of their numbers and the growth of their community across Europe, the Turkish diaspora is historically known for low levels of integration in the European countries in which they live. Poor integration is due, in part, to immigrants' desire to remain bonded with their own communities rather than bridging with members of the receiving society (Amelina and Faist 2008).

Based on offline and online quantitative and qualitative surveys conducted with Turkish minorities in Belgium, the Netherlands and Germany between November 2013 and May 2014 $(n=967)$, this study aims to how bonding and bridging social capital can explain the degree of integration experienced by European ethnic minorities' from the Turkish diaspora in their respective receiving countries. Specifically, this examines the impact the role of social media and mainstream media use on immigrants' social integration.

\section{Policies Toward Ethnic Minorities in Post-9/11 Europe}

Western European societies have long been reluctant to accept that migration has irreversibly transformed their countries socially, economically, and culturally. Accordingly, migrants who arrived in the 1960s were first considered 'guests' and later 'foreigners' (Wets, 2006). It was only in the 1990s that Germany officially declared itself a country that welcomed immigration (Bozdağ, 2014), while in Belgium and the Netherlands the first integration acts date to the 1980s (d'Haenens, 2009; Ogan and d'Haenens, 2012). This recognition in legal terms came with new measures and institutions to foster integration, governments realized that successful integration 
policy had to be directed towards both ethnic minorities and the majority populations. To do so, they had to overcome 'structural discrimination' affecting ethnic minorities (Council of Europe, 1991). Despite good intentions, the models of integration contained major flaws, eventually leading to higher levels of social inequality, appeals to nationalism and cultural homogeneity (Wieviorka, 2014).

The uneven integration of ethnic minorities into social and economic life across Europe is an increasingly important issue at a time when some European countries have been retreating from multiculturalism as their core public integration policy (Mattelart \& d'Haenens, 2014). Crul and Schneider (2010) argue that mobility pathways, cultural participation, and feelings of belonging are heavily dependent on the societal contexts at the receiving end, both nationally and locally. In other words, Europe consists of multinational settings with impressively diverse institutional arrangements for newcomers. These arrangements may differ greatly from country to country, and even from city to city.

These contexts for reception are crucial in the management of inequalities. Ersanilli and Koopmans's (2011) work on ethnic retention and host culture adoption, which also focuses on Turkish immigrants in Germany and the Netherlands, finds only moderate effects when it comes to actual socio-cultural integration among residents of Turkish origin across three countries, and integration policies do not matter in terms of the effect size.

\section{Integration Policy Typologies under Scrutiny in Belgium, Germany, and the Netherlands}

Extensive literature has assessed the value of multiculturalist, assimilationist and exclusionist models exists (e.g., Castles, 1995). In their evolving responses to ethnic diversity, not all European countries have shifted equally from multiculturalist to assimilationist approaches. Not surprisingly, political discourse regarding nation-states and nationalism reveal a variety of definitions of citizenship. 
Following a volatile integration path with assimilationist traits, Belgium's division between Flemish and Francophone majorities has complicated its ability to coherently choose a stance towards immigrants and other minorities (Jacobs, 1999). As a consequence of the country's decentralized makeup, concrete diversity management is de facto left to mayors and city councils at the local level. The Netherlands made the clearest shift from multiculturalist towards assimilationist integration (Scholten and Holzhacker 2009). This shift was not inspired by the actual facts related to the economic and cultural integration process and progress, but rather due to "popular anxiety provoked by profound changes in Dutch society" (see Entzinger, 2014: 693). Germany has only recently (since the 2000s) come to an "integration consensus" (Loch, 2014; 675), acknowledging that multiculturalism has led to social exclusion and urban ghettoization, thus requiring a reevaluation of constituent citizenship categories as part of a new 'us' (Bozdağ, 2014).

Acknowledging the retreat from a 'liberal' interpretation of multiculturalism as a common policy shift for all three countries under study (Kymlicka, 1995), we now focus on the many residents belonging to the Turkish diaspora in those three countries, immigrants have come to these countries in consecutive migration phases over the last five decades. While the 1960s were characterized by the export of excess labour, family reunification was central in the 1970s and 1980s. Later, refugees, and asylum seekers dominated migration from Turkey in the 1990s, and clandestine migration occurred with greater frequency in the 2000s (Guiraudon, 2000). Today, the Turkey-to-Western Europe migration movement is no longer a one-way street, as the experience of ethnic discrimination has recently influenced a return to Turkey.

Although integration is multifaceted and difficult to measure, a well-known index is the Migrant Integration Policy Index (MIPEX), which compares the opportunities provided to migrants by EU Member States and four non-EU countries' governments promoting and/or facilitating their integration. The MIPEX covers seven policy areas laid out in 148 policy 
indicators, which make up a migrant's trajectory towards full citizenship. These policies cover labour access, family reunion, long-term residence, political participation, access to nationality, anti-discrimination, and education. In their comparative review of six integration indices, Jedwab and Soroka (2014) assess MIPEX. The authors argue that it offers the most comprehensive set of economic and social indicators, although it captures the 'best practices' in regard to policies and not actual integration outcomes. MIPEX also includes 15 different indicators of political integration including voting rights, political liberties, consultation, and funding policies supporting immigrant groups.

The 2014 MIPEX scores for our three target countries ranks Belgium seventh among the 38 countries with 67 points, as part of a group of countries including Norway, Canada, and Australia. Table 1 shows the change of country scores since 2010, indicating that Belgium improved its score by two points between 2010 and 2014. Germany is ranked 10th on the list with an overall score of 61 after having lost three points between 2010-2014. The Netherlands is ranked 11th with a score of 60 points, having lost eight points between the 2010-2014 period, reflecting more restrictive integration policies on equal rights and opportunities for immigrants. Integration policies among the 38 countries score, on average, 52, indicating that integration policies in these developed democracies generate considerable obstacles for immigrants to fully participate in economic, social, and democratic life. Belgium, the Netherlands, and Germany score above average on the MIPEX but the decrease of eight points over four years for the Netherlands requires a closer look at the changes in migration policies adopted between 2010 and 2014.

While Germany (86) scores the highest in terms of labour market mobility, Belgium ranks lowest (64) in this domain. Compared to the other two countries, Belgium scores highest when it comes to family reunion, education, permanent residence, and anti-discrimination. While Germany has the highest scores compared to the other two countries on political 
participation and access to citizenship, it ranks the lowest on anti-discrimination (58) compared to Belgium (78) and the Netherlands (73). Another significant finding is Belgium's (86) score on permanent residence that outstrips the Netherlands (55) and Germany (60) by a considerable number of points. The integration policies in the Netherlands seem to fall in between those in Germany and Belgium with high scores on labour market mobility and anti-discrimination. The Netherlands has scores in the $50 \mathrm{~s}$ on indicators related to social rights of migrants like education, family reunion, and permanent residence. Notwithstanding their similarities, the three countries differ with respect to social, economic, and political indicators, thus allowing different access levels to various social, economic and political resources as migrants enter their respective societies and markets.

TABLE 1. Migrant Integration Policy Index (MIPEX), Overview, 2014

\begin{tabular}{|l|l|l|l|}
\hline & $\begin{array}{l}\text { Belgium } \\
\%\end{array}$ & $\begin{array}{l}\text { The Netherlands } \\
\%\end{array}$ & $\begin{array}{l}\text { Germany } \\
\%\end{array}$ \\
\hline Overall Score & $\mathbf{6 7}$ & 60 & 61 \\
\hline Labour Market Mobility & 64 & 73 & $\mathbf{8 6}$ \\
\hline Family Reunion & $\mathbf{7 2}$ & 56 & 57 \\
\hline Education & $\mathbf{6 1}$ & 50 & 47 \\
\hline Health & 53 & $\mathbf{5 5}$ & 43 \\
\hline Political Participation & 57 & 52 & $\mathbf{6 3}$ \\
\hline Permanent Residence & $\mathbf{8 6}$ & 55 & 60 \\
\hline Access to Nationality & 69 & 66 & $\mathbf{7 2}$ \\
\hline Anti- Discrimination & $\mathbf{7 8}$ & 73 & 58 \\
\hline
\end{tabular}

Meaning of the scores: $0 \%$ Critically unfavorable; 1-20\% Unfavorable; $21-40 \%$ Slightly Unfavorable;41-59\% Halfway to Best Practice; 60-79\% Slightly favorable; 80-99\% Favorable; $100 \%$ Best practice (See www.mipex.eu).

\section{Integration, Social Capital, and the Use of Social Media}

Integration is an issue that mainly concerns ethnic minorities in their attempt to be accepted by the majority population in a host society. The socio-economic integration of ethnic minorities in a host society serves as a test for maintaining social order (Burt, 2001). The lack of a specific 
definition is indicative of the wide range of agents responsible for integration, including not just immigrants, but also host country communities, governments and state bodies, among others (Penninx, 2003).

One approach to deal with the integration of immigrants is to turn to the theory of social capital. This theory suggests that individuals who are well-equipped with the resources to build a social network and share the resources of others can succeed better in achieving their objectives (Burt, 2001). In addition, social capital theory suggests that, people will invest in relationships with others because of the expected value of the resources gained as a result of these relations (Flap and Völker, 2004; Lancee, 2010).

Research on social capital distinguishes between 'bonding' and 'bridging'. Bonding refers to links formed within a group, while bridging comprises connections between distinct groups (Putnam, 2001; Woolcock and Naryan, 2000). Putnam (2001) argued that the connections formed between families and close groups of friends are sustained through the process of bonding, whereas bridging is responsible for forming and maintaining network relationships between individuals who are not closely connected or who were previously unknown to each other.

In his research on employment-seeking, Granovetter (1973) categorized relationships formed through bonding as strong connections and those formed through bridging as weak connections. He found the latter to be more effective when attempting to achieve a specific outcome, in his case the successful acquisition of employment (Imani Giglou et al., 2016). Successful integration of minorities in terms of social capital can be determined by the presence of a mix of both bonding and bridging capital. However, bonding is seen to be predominant amongst immigrants (Burt, 2001), who are repeatedly characterized as a group with a tightly bound, often closed and isolated, social network (Fernandez-Kelly, 1995). 
While research has recognized that integration within conventional social networks, for instance, into a local community, is related to social networks (Grieve et al., 2013), the relationship between social media use and the improved integration of ethnic minorities is still an under-explored field. Yet, increased usage of social media by ethnic minorities in recent years has been documented. De Kool's (2015) study on the media preferences of thirdgeneration Turkish-Dutch immigrants in the Netherlands notes a shift from transnational Turkish television as their primary media source to online media, with wide use of social media. Such shift enables researchers to clarify the expanding role the role media plays in the everyday lives of ethnic minorities.

Social media resolves social and cultural differences by uniting people from diverse backgrounds and positively influencing their integration (Park et al., 2014). The transnational channels of communication opened up by social media enable new possibilities for interacting within a community, whether social or virtual (Dekker and Siegel, 2013; Mittelstädt and Odag, 2015).

Social media facilitate strategies that engage with online resources in order to achieve social integration, which may vary from the established offline procedures, leading Mittelstädt and Odag (2015) to propose a new interdisciplinary conceptual framework distinguishing online integration in virtual communities from offline integration in society, based on their study of the social media use among ethnic minorities in Germany, including the Turkish diaspora.

However, social media can similarly enhance in-group cohesion, as people from ethnic minorities can join individuals of their own ethnicity, socializing in their 'home' language to the detriment of their integration in society, as Peeters and d'Haenens (2005) found in their study on integration and media use among Turkish, Moroccan, Surinamese and Antillean youth in the Netherlands. Therefore, acknowledging and understanding the differences between the 
types of integration that occur in online and offline contexts is essential to categorize the impact of social and mainstream media, including television, newspapers, etc., on ethnic minorities and the process of social integration and to clarify the actual direction of that impact (Mittelstädt and Odag, 2015).

In the ongoing debates on the relationship between media use and integration among ethnic minorities, some scholars propose diasporic frameworks for understanding the complicated dynamics of identity, place, communication and belonging. Georgiou (2005) explores the potentials of diasporic media in Europe, arguing that diasporic media cultures challenge the limits of European universalism and diasporic particularisms yet are not necessarily opposed to the universalistic projects of Europe. In other words, Christiansen (2004) utilizes a diaspora framework for understanding media practices of contemporary immigrants in Europe in the context of mainstream concerns over the impact of use of transnational media on integration processes. In their exploration of the development of transnational television from Turkey, Aksoy and Robins (2000) argue that a diverse Turkish television culture enables an array of expressions of what it means to be Turkish and critical engagement with one's own sense of identity as a member of the Turkish diaspora.

\section{Research Aims and Questions}

The main aim of the study is to identify how social capital, in terms of bridging and bonding, can explain the degree of integration of ethnic minorities. We investigate the effects of mainstream and social media use, and of socio-demographic characteristics of the respondents on their degree of integration in their host country.

This brings us to the following research questions:

RQ1: What is the profile of the respondents in the countries under study? 
RQ2: What impact does bridging and bonding social capital have on the degree of integration among the Turkish diaspora across the three countries under study?

RQ3: How does exposure to mainstream and social media affect the degree of integration among the Turkish diaspora?

RQ4: How do socio-demographic characteristics affect the degree of integration of the Turkish diaspora?

RQ5: What between-country differences can be detected with regard to social capital building and integration?

RQ6: In what ways do the MIPEX scores correspond to or differ from the lived experiences regarding social capital building and integration in the countries under study?

\section{Data and Methods}

Offline and online surveys were conducted from November 2013 until May 2014. The survey participants $(n=967)$ were Turkish minorities, either first-generation immigrants or children/grandchildren of workers, students or political asylum seekers who left Turkey to reside in Belgium $(n=332)$, Germany $(n=320)$, or the Netherlands $(n=315)$. Random sampling was impossible as no database of names and telephone numbers of the target population is accessible.

\section{Recruitment of Participants}

Locating the Turkish diaspora, both on- and offline, was the main challenge for this research because of the lack of reliable statistics. The online survey participants were recruited through Kurdish/Turkish diaspora organizations and social media groups (Facebook and Twitter). The offline survey respondents were mainly contacted through businesses and community groups in predominantly Turkish neighborhoods where potential participants were known to reside. In addition, we used keywords to search Facebook for group pages of Turkish diaspora 
organizations. Thereafter, we asked the administrators for permission to join their online groups. While some groups rejected our request, this approach worked well, as we were able to initially join 486 Facebook groups (Ogan et al., 2016).

To aid with recruitment efforts, we used the Gezi Park protests in Turkey, a key moment of civilian resistance, which began on May 28, 2013, and a period in which political norms were challenged, as an entry point to engage potential participants. Diasporic involvement was notable in the three countries under study, and it created a unique opportunity to recruit participants for our study (Imani Giglou and et al., 2016). As a result of using the Gezi Park protests for recruitment purposes, the respondents were typically young and had received higher education. Hence, our results may not be representative of the full diasporic population in each of the countries under consideration.

\section{Online and Offline Questionnaire}

The questionnaire consisted of 65 questions ${ }^{1}$ and was offered in Turkish, English, Dutch, and German. Respondents could complete the survey online using Qualtrics or offline in their language of choice. Offline questionnaires were distributed and later retrieved at events, at headquarters of organizations, and at social gatherings. The offline survey responses constituted $11 \%(n=107)$ of the total, while the remaining $89 \%(n=860)$ completed it online. A response rate could not be determined as many offline questionnaires were not returned and could not be tracked. Online response rate could also not be calculated since the number of potential respondents who read the request to participate but did not complete the survey was unknown. Qualtrics, the survey engine, controlled online duplications by assigning a unique identification number corresponding to the IP addresses of the respondent's computer and Internet connection (Ogan et al., 2016). 
In our survey, characteristics of those who participated in the survey offline were not much different from the online respondents in terms of their demographic characteristics. Although offline respondents were somewhat older than the online survey takers, other differences from those who took the survey online were not pronounced (Ogan et al., 2016).

\section{Research Variables and Measurement}

Measurement for degree of integration and social capital was performed using integration as the dependent latent variable and social capital as independent latent variable and mediator. The degree of integration was measured by the level of proficiency in the language of the country of residence, level of education, occupation, sense of belonging to Turkey, sense of belonging to the host country, citizenship from a country other than Turkey, and the degree of satisfaction with the support of ethnic minorities in the host country.

Social capital was measured through bridging and bonding concepts. Bridging was constructed from variables measuring the number of close friends from the host country; percentage of host friends out of total friends on Facebook, and membership in associations where interactions with host members occur. Bonding was measured through the number of close Turkish friends, percentage of Turkish friends on Facebook, and attendance at meetings regarding problems faced by Turkish people (i.e. Gezi movement-related).

Effects of social capital, mainstream and social media, and socio-demographic variables on integration were measured through multiple group analysis comparing cross-country effects of integration, bonding, and bridging.

\section{Measurement Model (CFA) of Integration}

The analyses were conducted in Amos using confirmatory factor analysis. The fit metric of CFA of integration was $2.99\left(\chi^{2}=29.98 ; \mathrm{df}=10\right)$, an acceptable model fit. Confirmatory factor 
analysis on the measurement model of integration was conducted with integration as the latent variable. All the variables used in the construction of integration were positively significant, except the sense of belonging to Turkey, which had a significantly negative effect on the degree of integration (Figure 1). Among all variables, citizenship of the country of residence had the highest positive effect on integration, while belonging to Turkey had the lowest effect.

FIGURE 1. CFA or Measurement Model of Integration

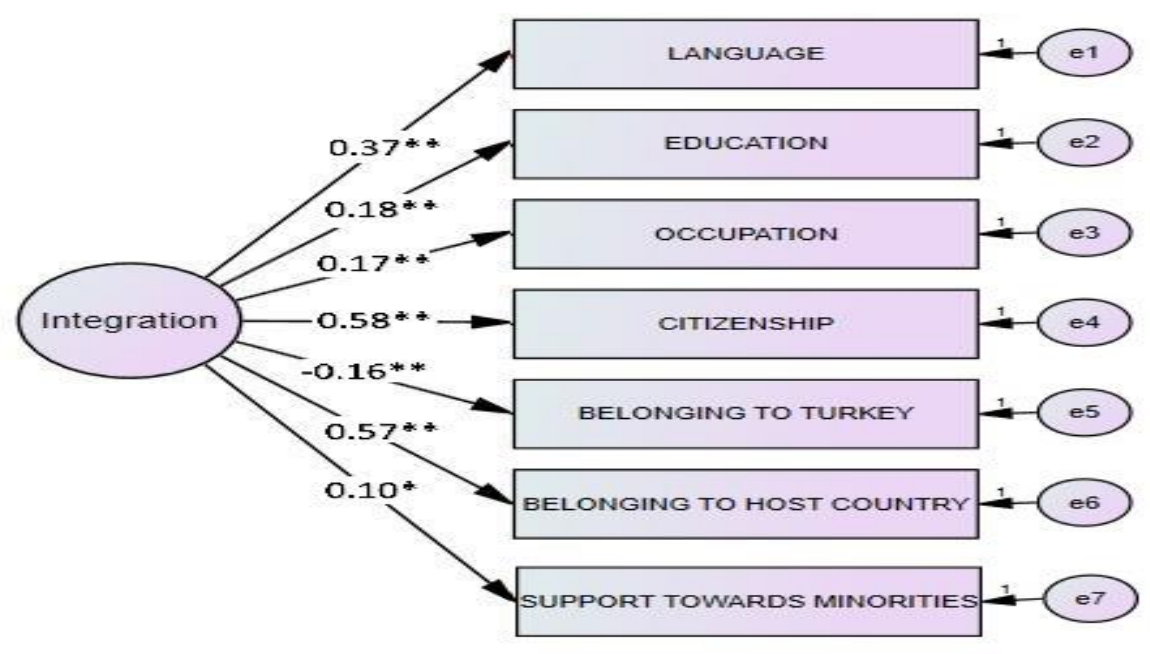

Important fit Indices: $\mathrm{X} 2=29.98, \mathrm{DF}=10, \mathrm{X} 2$ over $\mathrm{DF}=2.60, \mathrm{RMSEA}=0.04, \mathrm{GFI}=0.99$, $\mathrm{CFI}=0.95, \mathrm{IFI}=0.95, \mathrm{TLI}=0.91 . * \mathrm{p}<0.05$ and $* * \mathrm{p}<0.01$.

\section{Measurement Model (CFA) of Social Capital}

Confirmatory factor analysis on social capital was conducted with bonding and bridging as dependent variables. All the variables used in the construction of bridging and bonding had significant positive effects on them (Figure 2). The number of Turkish friends on Facebook had the highest positive effect on bonding, while attendance at meetings of organizations to which respondents belonged had the least effect. For bridging, the number of close 'native' friends had the highest effect and the attendance at meetings had the lowest effect. 


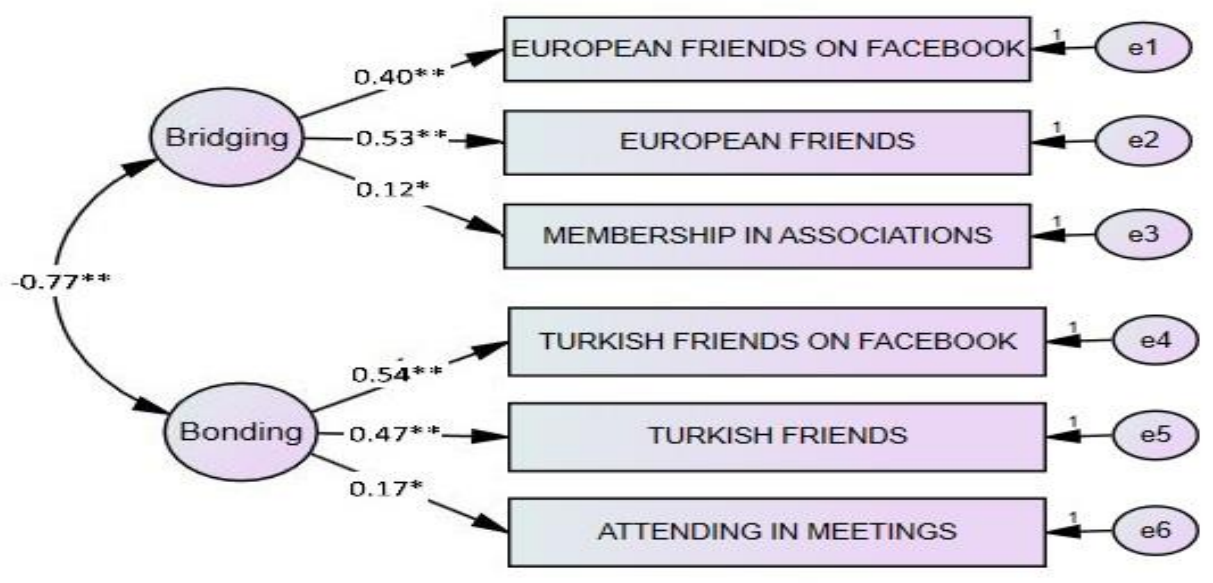

Important fit Indices: $\mathrm{X} 2=15.13, \mathrm{DF}=4, \mathrm{X} 2$ over $\mathrm{DF}=3.78, \mathrm{RMSEA}=0.05, \mathrm{GFI}=0.99$, $\mathrm{CFI}=0.98, \mathrm{IFI}=0.98, \mathrm{TLI}=0.91 . * \mathrm{p}<0.05$ and $* * \mathrm{p}<0.01$.

\section{Findings}

\section{Respondents' socio-demographics}

The respondents' age range was between 17 and 75, while the mean age was 31 years \pm 10.059 for those living in Belgium and the Netherlands $(\mathrm{SD}= \pm 10.877)$, and 32 years \pm 11.470 for respondents in Germany. The male-female ratio was $56 \%$ to $44 \%$ for Belgium and the Netherlands, and $47 \%$ to $53 \%$ for Germany. On average, the respondents were mainly high school or vocational graduates across the three countries. Most of the respondents were single (55.4\% in Belgium, $63.8 \%$ in the Netherlands and $66.9 \%$ in Belgium). The ratio of non-students to students was similar for participants in Germany and the Netherlands (almost 51\%-49\%) whereas the ratio in Belgium was $44.6 \%$ to $55.4 \%$. About $53.5 \%$ of Belgian and German participants were born in Turkey, whereas $48.1 \%$ of the Dutch participants were born in Turkey. 
The ratio of Turkish to non-Turkish citizens was $90.6 \%$ to $9.4 \%$ in Belgium, $88.4 \%$ to $11.6 \%$ in the Netherlands, and $63.9 \%$ to $36.1 \%$ in Germany. Additionally, $34.4 \%$ of Belgian respondents were Turkish citizens whereas the case for the Dutch and German respondents was $40.2 \%$ and $22 \%$ respectively. Most of the respondents knew how to speak Turkish or Kurdish (70.1\% for Belgium, $61.3 \%$ for Netherlands and $65.3 \%$ for Germany), although a small portion did not speak Turkish (4.3\% for Belgium, $0.8 \%$ for the Netherlands and 5.5\% for Germany). In all three countries, ethnic minorities tended to live in similar neighborhoods where shops and services were run by others of Turkish/Kurdish ethnicity, creating less need to learn the languages of the countries where they live, with housing preferences being coined 'voluntary segregation' (see Entzinger, 2014). The average length of stay for respondents in Belgium, the Netherlands and Germany was 18.8, 21.5 and 19.9 years respectively. Hence, on average the respondents have spent a major portion of their lives in their host countries.

\section{Media use}

Table 2 focuses on the degree of media use. Frequent Internet use was common in participants of all three countries (61.8\% for Belgium, $68.3 \%$ for Netherlands, and $64.1 \%$ for Germany) with no major cross-country differences. There were no significant differences between respondents from the three countries as to having a Twitter account, frequently using traditional media; there were also no significant differences across countries regarding frequent viewers of European and Turkish television. However, there were significant differences between Germany (59.9\%) and the other two countries (nearly 50\%) with respect to reading online and offline Turkish newspapers frequently. Participants from the Netherlands read European newspapers more frequently (56.1\%) compared to their Belgian (46\%) and German (44.1\%) counterparts. There were also significant differences between respondents from Germany (42.6\%) and those from Belgium (34.3\%) and the Netherlands (29.4\%) in selecting Turkish 
news channels as their news sources of choice. Belgian respondents (53.7\%) were significantly different in terms of frequent social media usage when compared to the Dutch $(44.4 \%)$ and German (43.5\%) respondents.

TABLE 2. Media Use by Respondents

\begin{tabular}{|c|c|c|c|c|}
\hline & $\begin{array}{l}\text { Belgium } \\
\%\end{array}$ & $\begin{array}{l}\text { The } \\
\text { Netherlands } \\
\%\end{array}$ & $\begin{array}{l}\text { Germany } \\
\%\end{array}$ & Significance \\
\hline $\begin{array}{l}\text { Internet Use Frequency } \\
\text { (all/most of time) }\end{array}$ & 61.8 & 68.3 & 64.1 & $X^{2}=\mathrm{n} . \mathrm{s}$. \\
\hline Have a Twitter account & 60.5 & 65.3 & 57.3 & $\mathrm{Phi}=$ n.s. \\
\hline $\begin{array}{l}\text { Turkish Newspaper Reading } \\
\text { Frequency (Online/Offline) } \\
\text { (Every Day/Nearly Every } \\
\text { Day) }\end{array}$ & 50.8 & 51.6 & 59.9 & $\begin{array}{l}\mathrm{V}=.103 \\
\mathrm{p}=0.10\end{array}$ \\
\hline $\begin{array}{l}\text { European Newspaper Reading } \\
\text { Frequency (Online/Offline) } \\
\text { (Every Day/Nearly Every } \\
\text { Day) }\end{array}$ & 46 & 56.1 & 44.1 & $\begin{array}{l}\mathrm{V}=.093 \\
\mathrm{p}=0.33\end{array}$ \\
\hline $\begin{array}{l}\text { Turkish Television Viewing } \\
\text { (Several hours/day) }\end{array}$ & 20.9 & 24.1 & 20.1 & $\mathrm{x}^{2}=\mathrm{n} . \mathrm{s}$. \\
\hline $\begin{array}{l}\text { European Television Viewing } \\
\text { (Several hours/day) }\end{array}$ & 12.9 & 19.2 & 16.7 & $\mathrm{x}^{2}=$ n.s. \\
\hline $\begin{array}{l}\text { News Channel of Choice } \\
\text { (Selected Turkish) }\end{array}$ & 34.3 & 29.4 & 42.6 & $\begin{array}{l}x^{2}=12.293 \\
p=0.15\end{array}$ \\
\hline $\begin{array}{l}\text { Use of Social Media } \\
\text { (Most of time) }\end{array}$ & 53.7 & 44.4 & 43.5 & $\begin{array}{l}\mathrm{V}=.099 \\
\mathrm{P}=.017\end{array}$ \\
\hline $\begin{array}{l}\text { Use of Traditional Media } \\
\text { (Most of time) }\end{array}$ & 44.5 & 42.2 & 42.8 & $\mathrm{~V}=\mathrm{n} . \mathrm{s}$. \\
\hline
\end{tabular}


National integration policies and support of ethnic minorities

Inquiring about the level of satisfaction with national integration policies in the three countries, $32.7 \%$ of the Belgian Turks said they were satisfied compared to $28.2 \%$ of the respondents from Netherlands and $25 \%$ of those in Germany. Similarly, $38.8 \%$ of the respondents from Germany were dissatisfied compared to their counterparts in Belgium (23.7\%) and Netherlands (27.1\%). Among respondents who were dissatisfied with integration policies, more of those living in Germany said it was due to racist attitudes (42.4\%) than in Belgium (33.3) or the Netherlands (37.9\%). Moreover, $33.3 \%$ of respondents in Belgium said they never encountered discrimination compared to $20 \%$ of respondents in the Netherlands and Germany respectively.

TABLE 3. What is the level of satisfaction of the Turkish diaspora towards the national integration policies among the three countries?

\begin{tabular}{lllll}
\hline & Belgium & The Netherlands & Germany & Significance \\
& $\%$ & $\%$ & $\%$ & \\
Satisfied & 32.7 & 28.2 & 25.0 & \\
$\begin{array}{l}\text { Neither satisfied/nor } \\
\text { unsatisfied }\end{array}$ & 43.7 & 44.7 & & Cramer's $\quad$ V= \\
& & & 36.2 & 0.101 \\
Not satisfied & 23.7 & 27.1 & 38.8 & \\
\end{tabular}

Degree of integration explained by social capital and media use

Figure 3 illustrates the theoretical model along with the relationships between the latent variables (Bridging, Bonding, and Integration). All three latent variables were regressed upon use of social media and European and Turkish mainstream media, as well as socio-demographic variables such as place of birth, marital status, age, length of stay in Europe, gender, sense of belonging to a faith, Turkish citizenship status. 
FIGURE 3. Testing the effect of Social Capital, Social Media and Socio-demographic variables on degree of integration

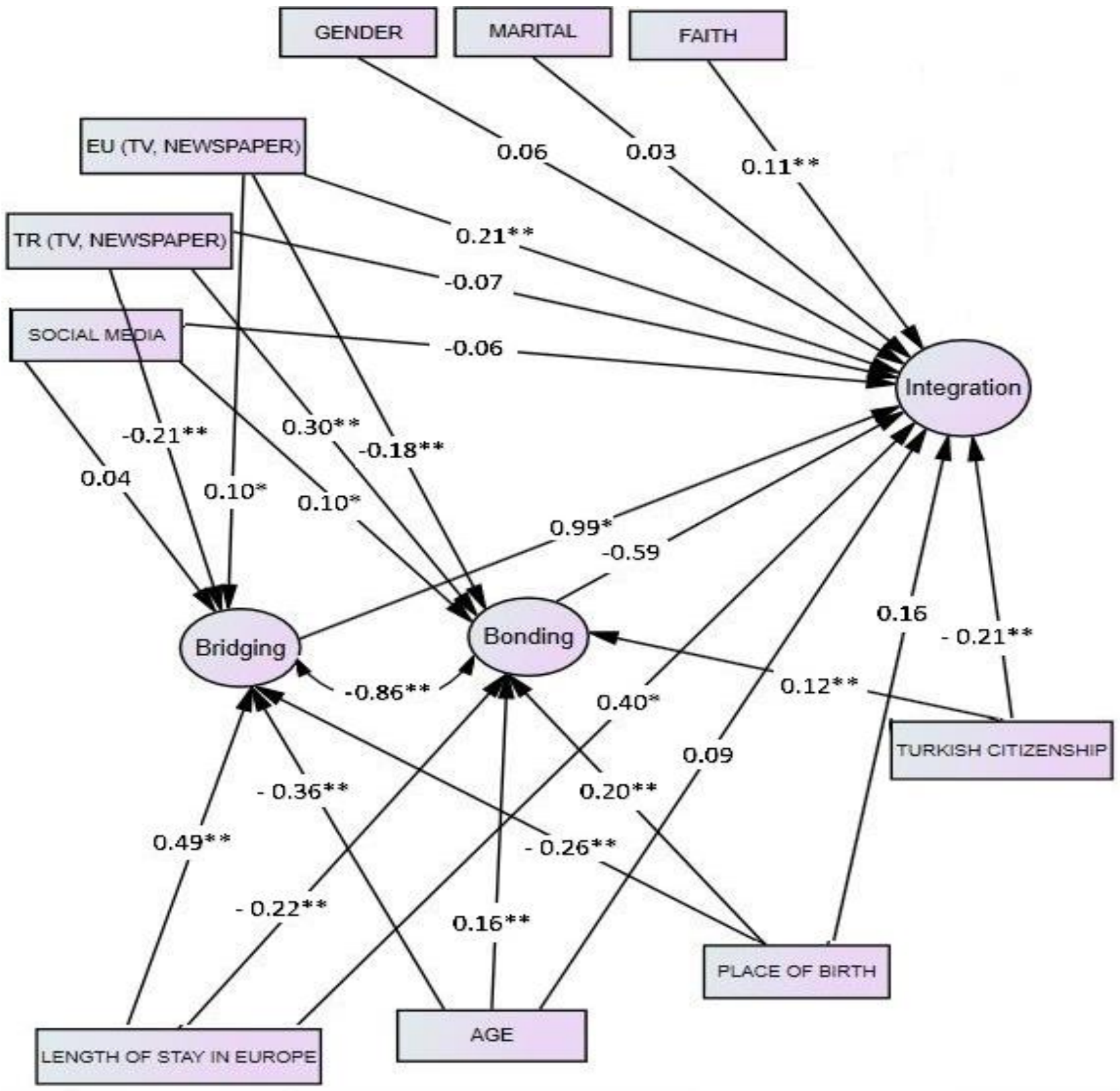

Important fit indices after Modifying: Chi-Square=911.24, DF=209, Chi-Square to DF $=4.36$, $\mathrm{CFI}=0.91, \mathrm{GFI}=0.93, \mathrm{IFI}=0.91, \mathrm{TLI}=0.89, \mathrm{RMSEA}=0.06$.

$*$ display $\mathrm{p}<0.05$ and $* *$ display $\mathrm{p}<0.01$.

Overall, beyond the country level, the results of the structural equation modeling for testing associations among independent and dependent variables illustrate that being a Turkish citizen significantly decreases $(\lambda=-.213 ; p=.001)$ the degree of integration, while a sense of belonging 
to a faith community $(\lambda=.111 ; p=.001)$, length of stay in Europe $(\lambda=.395 ; p=.05)$, exposure to European TV and newspapers $(\lambda=.212 ; \mathrm{p}<.001)$ and bridging $(\lambda=1.132 ; \mathrm{p}=.05)$ positively impact the degree of integration.

Unsurprisingly, bridging was positively affected by the length of stay in Europe $(\lambda=$ $.487 ; \mathrm{p}<.001)$ and an increased viewership of mainstream European media $(\lambda=.104 ; \mathrm{p}=.021)$, while it is negatively affected by age $(\lambda=-.363 ; p<.001)$, place of birth $(\lambda=-.261 ; p<.001)$ and Turkish mainstream media $(\lambda=-.208 ; \mathrm{p}<.001)$. Therefore, the increase in bridging is explained by the use of mainstream European media (TV and newspapers), being born in Europe, length of stay in the European Union, and being younger (see table 4).

The results for bonding were the opposite of those for bridging, as bonding was increased by being a Turkish citizen $(\lambda=.121 ; \mathrm{p}<.001)$, age $(\lambda=.158 ; \mathrm{p}=.002)$, being born in Turkey $(\lambda=.198 ; \mathrm{p}<.001)$, viewer- and readership of Turkish TV and newspapers $(\lambda=.303 ; \mathrm{p}$ $<.001)$, and social media $(\lambda=.088 ; \mathrm{p}=.013)$, whereas length of stay in Europe $(\lambda=-.215 ; \mathrm{p}<$ $.001)$ and viewer- and readership of European TV and newspapers $(\lambda=-.176 ; \mathrm{p}<.001)$ decreased bonding. Therefore, based on the regression weights, more bonding was explained by higher viewership of Turkish mass media, use of social media, being born in Turkey, being a Turkish citizen, and being older (see table 4).

TABLE 4. Regression Weights for modified model: Maximum Likelihood estimation of effects among variables

\begin{tabular}{llcclll}
\hline Dependent & Independent & Beta & S.E. & Z Statistics & P & Standardized Beta \\
\hline Bridging & Length of stay in EU & 5.939 & .704 & 8.435 & $* * *$ & .487 \\
\hline Bridging & Age & -4.149 & .676 & -6.140 & $* * *$ & -.363 \\
\hline Bridging & Place of birth & -8.186 & 1.995 & -4.103 & $* * *$ & -.261 \\
\hline Bonding & Turkish citizen & 6.316 & 1.539 & 4.103 & $* * *$ & .121 \\
\hline Bonding & Age & 2.147 & .695 & 3.089 & .002 & .158 \\
\hline Bonding & Length of stay in EU & -3.119 & .725 & -4.305 & $* * *$ & -.215 \\
\hline
\end{tabular}




\begin{tabular}{llcclll}
\hline Dependent & Independent & Beta & S.E. & Z Statistics & P & Standardized Beta \\
\hline Bonding & Place of birth & 7.419 & 2.061 & 3.600 & $* * *$ & .198 \\
\hline Bridging & Social media use & .734 & .705 & 1.041 & .298 & .042 \\
\hline Bridging & EU mainstream media & 1.557 & .676 & 2.302 & .021 & .104 \\
\hline Bridging & Turkish mainstream media & -3.022 & .633 & -4.775 & $* * *$ & -.208 \\
\hline Bonding & Social media use & 1.816 & .728 & 2.494 & .013 & .088 \\
\hline Bonding & EU mainstream media & -3.128 & .699 & -4.476 & $* * *$ & -.176 \\
\hline Bonding & Turkish mainstream media & 5.238 & .654 & 8.010 & $* * *$ & .303 \\
\hline Integration & Faith & .029 & .009 & 3.203 & .001 & .111 \\
\hline Integration & Gender & .025 & .015 & 1.728 & .084 & .055 \\
\hline Integration & Place of birth & .070 & .046 & 1.511 & .131 & .156 \\
\hline Integration & Length of stay EU & .068 & .036 & 1.920 & .055 & .395 \\
\hline Integration & Age & .015 & .026 & .586 & .558 & .094 \\
\hline Integration & Turkish citizen & -.133 & .041 & -3.275 & .001 & -.213 \\
\hline Integration & Bridging & .016 & .008 & 1.960 & .050 & 1.132 \\
\hline Integration & Bonding & .007 & .005 & 1.368 & .171 & .588 \\
\hline Integration & Social media use & -.016 & .019 & -.833 & .405 & -.065 \\
\hline Integration & EU mainstream media & .045 & .013 & 3.549 & $* * *$ & .212 \\
\hline Integration & Turkish mainstream media & -.015 & .013 & -1.167 & .243 & -.073 \\
\hline & & & & & & \\
\hline
\end{tabular}

We will now turn to which variables differed across the countries in forming the latent variables and also observe which predictors affected the dependent variables similarly or differently across the countries.

\section{Integration}

In the regression predictors, having a sense of belonging to a faith community with shared beliefs significantly increased the degree of integration of the Turkish diaspora in Belgium ( $\lambda$ $=.136 ; \mathrm{p}<.05)$ and the Netherlands $(\lambda=.271 ; \mathrm{p}<.01)$ compared to those residing in Germany $(\lambda=-.056 ; \mathrm{ns})$ The effect of gender on integration was not significant in the Netherlands and 
Germany. In Belgium, however, gender $(\lambda=.171 ; \mathrm{p}<.01)$ positively affected integration in the sense that males in Belgium are more integrated than females (see table 5).

Length of stay in the European Union $(\lambda=.604 ; \mathrm{p}<.01)$ significantly increased the degree of integration of the Turkish diaspora in Germany, and had the highest positive effect on integration for Turkish citizens in Germany compared to those residing in the Netherlands and Belgium, where the effect was not significant. Having Turkish citizenship significantly decreased the degree of integration only in the Netherlands $(\lambda=-.164 ; p<.05)$ and Germany $(\lambda=$ -.306; $\mathrm{p}<.01)$. The effect was highest in Germany compared to the Netherlands; however, twoby-two comparison showed no cross-country differences (see table 5).

The effects of use of European TV and newspapers were similar in the Netherlands and Germany, as they increased the degree of integration significantly in the Netherlands $(\lambda=.310$; $\mathrm{p}<.05)$ and Germany $(\lambda=.240 ; \mathrm{p}<.01)$. Cross-country comparison showed a similar effect for those residing in Belgium and the Netherlands, however, the effect in Belgium was not significant. Turkish TV viewership and newspaper readership $(\lambda=-.182 ; \mathrm{p}<.05)$ decreased the level of integration only in Germany, but not in Belgium and the Netherlands. While bridging $(\lambda=.092 ; \mathrm{p}<.05)$ increased integration significantly in Belgium, it did not affect the degree of integration of the Turkish diaspora in the Netherlands and Germany. Bonding did not show any significant effect on the degree of integration of the Turkish diaspora in any of the three countries (see table 5).

\section{Bridging}

Length of stay in the EU increased bridging significantly in Belgium $(\lambda=.063 ; p<.01)$, the Netherlands $(\lambda=.435 ; \mathrm{p}<.01)$, and Germany $(\lambda=.356 ; \mathrm{p}<.01)$. Two-by-two country analysis showed that the effect was similar for those residing in Belgium and the Netherlands and in the Netherlands and Germany, but different between Belgium and Germany (see table 5). 
With age bridging significantly decreased in Belgium $(\lambda=-.476 ; p<.01)$, the Netherlands $(\lambda=-.322 ; \mathrm{p}<.01)$, and Germany $(\lambda=-.200 ; \mathrm{p}<.05)$, which means that older Turkish people are not bridging as frequently with natives. Age had a similar effect on the bridging of the Turkish diaspora in Belgium and the Netherlands, though it had the highest negative effect on the bridging of those in Belgium compared to the Netherlands. Age also had a similar negative effect between the respondents in the Netherlands and Germany. However, it had the highest negative effect for those residing in the Netherlands compared to those residing in Germany. Overall, age had the highest negative effect on bridging of the respondents in Belgium compared to those who reside in the Netherlands and Germany (see table 5).

Place of birth had a significant negative effect on bridging in the Netherlands $(\lambda=-.367$; $\mathrm{p}<.01)$ and Germany $(\lambda=-.443 ; \mathrm{p}<.01)$. Therefore, respondents who were born in Turkey were less likely to communicate with people originating from the country where they live. The effect of place of birth was different for Turkish people in Belgium, but similar for the Turkish people in the Netherlands and Germany, though Germany had the highest negative effects compared to those who reside in the Netherlands (see table 5).

Exposure to Turkish TV and newspapers had a significant negative effect on bridging for the respondents residing in the Netherlands $(\lambda=-.355 ; \mathrm{p}<.01)$ and Germany $(\lambda=-.212$; $\mathrm{p}<.01)$. The two-by-two country comparison showed that the effects on bridging were similar between those residing in Belgium and Germany, though Germany showed the highest negative effect. The negative effects on bridging were similar in the Netherlands and Germany, but highest in the Netherlands. Exposure to European TV and newspapers had a positive effect on bridging for the Turkish residing in the three countries albeit not significant (see table 5). 


\section{Bonding}

Having Turkish citizenship had different effects on bonding in the three countries. It significantly increased bonding only in Belgium $(\lambda=.220 ; p<.01)$ and Germany $(\lambda=.154$; $\mathrm{p}<.01$ ), but did not play a significant role on the bonding of Turkish people residing in the Netherlands (see table 5).

Length of stay in the EU had the highest negative effect on bonding among Turkish citizens in Belgium. In other words, the longer they stay, the less they may bond with other Turks. Age had significantly positive effects on bonding in Belgium $(\lambda=.198 ; p<.05)$ and the Netherlands $(\lambda=.164 ; \mathrm{p}<.05)$, and its impact in Belgium was higher than in the Netherlands. Therefore, older respondents tended to bond more with others in the diaspora than did younger ones. Two-by-two country comparison showed no differences among the three countries. The length of stay in the EU significantly decreased bonding in all three countries, with the highest negative effect in Belgium. Therefore, people who are living in Europe longer are less likely to bond with other Turkish/Kurdish minorities than those who lived in Europe for a shorter time. Being born in Turkey significantly increased bonding in the Netherlands $(\lambda=.280 ; p<.01)$ and Germany $(\lambda=.256 ; \mathrm{p}<.01)$. The same trend, albeit not statistically significant, was shown in Belgium (see table 5).

Social media use significantly increased bonding only in Belgium $(\lambda=.166 ; \mathrm{p}<.01)$. European TV viewership and newspaper readership decreased bonding in the Netherlands $(\lambda=$ $-.073 ; \mathrm{p}<.01)$ and even more so in Germany $(\lambda=-.264 ; \mathrm{p}<.01)$. The effects were similar in Belgium, without being statistically significant. Exposure to Turkish TV media significantly increased bonding in all three countries with the highest positive effect in the Netherlands $(\lambda=$ $.361 ; \mathrm{p}<.01)$, compared to Germany $(\lambda=.350 ; \mathrm{p}<.01)$ and Belgium $(\lambda=.195 ; \mathrm{p}<.01)$ (see table $5)$. 
TABLE 5. Multiple group analysis results for comparison of effects among three countries -

Modified SEM model

\begin{tabular}{|c|c|c|c|c|}
\hline Variables & & & Country & \\
\hline Independent & Dependent & $\begin{array}{l}\text { Belgium } \\
\mathrm{n}=332\end{array}$ & $\begin{array}{l}\text { Netherlands } \\
n=315\end{array}$ & $\begin{array}{l}\text { Germany } \\
\mathrm{n}=320\end{array}$ \\
\hline Length of stay EU & & $0.063 * * \mathrm{a}$ & $0.435 * * a b$ & $0.356 * * \mathrm{~b}$ \\
\hline$\overline{\text { Age }}$ & & $-0.476^{* * a}$ & $-0.322 * * a b$ & $-0.200 * \mathrm{~b}$ \\
\hline Place of birth & Bridging & $-0.008^{\mathrm{a}}$ & $-0.367 * * \mathrm{~b}$ & $-0.443 * * \mathrm{~b}$ \\
\hline Social media use & & 0.028 & -0.002 & 0.043 \\
\hline$\overline{\text { EU mainstream media }}$ & & 0.083 & 0.070 & 0.122 \\
\hline Turkish mainstream media & & $-0.072^{\mathrm{a}}$ & $-0.355^{*} * \mathrm{~b}$ & $-0.212 * * \mathrm{ab}$ \\
\hline Turkish citizen & & $0.220 * * \mathrm{a}$ & $0.029^{b}$ & $0.154 * * \mathrm{c}$ \\
\hline$\overline{\text { Age }}$ & & $0.198^{*}$ & $0.164 *$ & 0.113 \\
\hline Length of stay EU & & $-0.267 * *$ & $-0.205^{*}$ & $-0.170 *$ \\
\hline Place of birth & Bonding & $0.048^{\mathrm{a}}$ & $0.280 * * \mathrm{~b}$ & $0.256^{* * a b}$ \\
\hline Social media use & & $0.166 * *$ & 0.053 & 0.062 \\
\hline EU mainstream media & & $-0.073^{\mathrm{a}}$ & $-0.175^{* * a b}$ & $-0.264 * * \mathrm{~b}$ \\
\hline Turkish mainstream media & & $0.195 * *$ & $0.361 * *$ & $0.350 * *$ \\
\hline Faith & & $0.136^{* a}$ & $0.271 * * a$ & $-0.056^{\mathrm{b}}$ \\
\hline Gender & & $0.171^{* * a}$ & $0.005^{\mathrm{b}}$ & $-0.069^{b}$ \\
\hline Place of birth & & 0.026 & 0.151 & 0.075 \\
\hline Length of stay EU & & $0.269^{\mathrm{a}}$ & $0.677^{\mathrm{ab}}$ & $0.604 * * \mathrm{~b}$ \\
\hline$\overline{\text { Age }}$ & Integration & 0.221 & -0.155 & -0.099 \\
\hline Turkish citizenship & & -0.141 & $-0.164 *$ & $-0.306^{* *}$ \\
\hline Social media use & & -0.082 & -0.024 & 0.014 \\
\hline EU mainstream media & & $0.118^{\mathrm{a}}$ & $0.310^{* a b}$ & $0.240 * * \mathrm{~b}$ \\
\hline Turkish mainstream media & & -0.034 & -0.043 & $-0.182 *$ \\
\hline Bridging & & $0.092 *$ & 0.478 & 0.510 \\
\hline$\overline{\text { Bonding }}$ & & -0.471 & -0.209 & -0.261 \\
\hline
\end{tabular}

Important fit Indices: $\mathrm{X} 2=1639.78, \mathrm{DF}=627, \mathrm{X} 2$ over $\mathrm{DF}=2.61, \mathrm{RMSEA}=0.04, \mathrm{GFI}=0.94$, $\mathrm{CFI}=0.92, \mathrm{IFI}=0.91, \mathrm{TLI}=0.89$. The alphabetical letters $\mathrm{a}, \mathrm{b}$, and $\mathrm{c}$ mark the similarities between the countries. For example if the letter ' $a$ ' is added to the observed beta coefficients of the three countries, it means that the effects on the latent variable under investigation were similar. If the same observed variable had beta coefficients marked as ' $a$ ', ' $b$ ', or ' $c$ ', then it means the effects were different. Thus similar alphabetic letters mean similar effects while different alphabetic letters mean different effects. Correlation between Bonding and Bridging for the three countries was $r=-0.80$ for Belgium, $r=-0.92$ for the Netherlands and $r=-0.76$ for Germany. All three correlations were significant $(\mathrm{p}<0.01)$.

$*$ display $\mathrm{P}<0.05$ and $* *$ display $\mathrm{P}<0.01$. 


\section{Discussion and Conclusion}

Our findings suggest significant variation in the degree of bridging and bonding social capital and integration among the Turkish diaspora across Belgium, the Netherlands and Germany. Overall, we found that the most integrated members of the Turkish diaspora were those who had lived in Europe the longest, took an interest in European mainstream media (TV and newspapers), were more frequently bridging and communicating with the receiving society, and had a sense of belonging to a faith. Our findings further suggested that being a Turkish citizen significantly decreases the degree of integration.

In addition to measuring the degree of integration, we also estimated the effectiveness of seven integration policy areas in the countries under consideration. To do so, each integration policy areas was assessed and given a score using MIPEX data. MIPEX, like the policy indicators, places responsibility for integration with both policymakers and with migrants. However, very little is known about the extent to which policies affect actual levels of immigrant integration, and if so in what direction these effects go. Our study attempts to contribute to this body of knowledge by capturing data from migrant respondents about their degree of integration, using the seven integration policy areas that the MIPEX provides.

For the purposes of this study, we have examined the attitudes and behaviors of migrants themselves. The comparison of the MIPEX scores with the results of our study identified whether the lived experiences of immigrants corresponded to or differed from these results, particularly in relation to integration, the satisfaction of the Turkish diaspora with the integration policies, and the support for ethnic minorities in the country of residency. Overall our data corresponded to the MIPEX results for the Turkish diaspora in Belgium, who tended to be more satisfied with the country's integration policies than their counterparts in the Netherlands and Germany. 
The sociological context for this study is defined by the current assimilationist policies and the aim of achieving integration into receiving societies. These frameworks, predominant in the countries considered here, are analyzed in light of the increasing cultural disparity between members of the receiving societies and those of ethnic minorities. For first-generation immigrants, key differences are seen to be religion, language, and nationality. The cultural disparity between the diaspora and the receiving society manifests itself in differences in levels of civic participation, professions, and income. Also evident are disparities in the sense of trust and perceived discrimination. In both the cultural majority and minority populations, the active and younger age groups are comparable in almost every lifestyle category, with the exception of religious views.

Religious belief was found to be a key variable in this research, as it was demonstrated that in the Turkish diaspora integration was positively impacted by a strong sense of religious affiliation. Specifically, religious belief is a significant predictor of the degree of integration in Belgium and the Netherlands, but not in Germany.

This finding contradicts studies that identify the presence of faith as a key reason for Muslim immigrants to experience difficulty integrating into the receiving society, potentially resulting in their marginalization. Some of these studies have argued that this marginalization could result in acts of violence against the host country (Stemmann, 2006). For this reason, the control of migration and ensuring of integration have become priority issues in the wake of the attacks in the United States on September 11, 2001 (Kaya, 2009). Similar policy proposals have also followed events such as the major influx of refugees from Syria and the violent attacks on civilians in Paris on November 13, 2015 and Brussels on March 22, 2016.

These concerns were challenged by our findings and several recent studies commissioned by different research centers, such as Gallup, Pew, the Institute for Social Policy 
and Understanding, and an Essex University research center (Moosavi, 2012). These studies consistently find that Muslims are well integrated and have a very strong sense of belonging to their receiving communities. This demonstrates the existence of a disparity between the perspectives that non-Muslims have of Muslim communities on the one hand, and the perspective they have of themselves on the other. This disparity is probably due to the assumption among non-Muslims that Muslims find it challenging to identify with their host community and that their loyalty is divided between the latter and their native identity.

\section{Language, Media Use and Integration Disparities}

Our findings show significant variation among Belgium, the Netherlands and Germany with regard to European and Turkish mainstream media use by respondents, leading to different effects for bonding and bridging in the three countries. Respondents in the Netherlands were more steeped in European mainstream media than their counterparts in Belgium and Germany. They reported reading European newspapers more frequently and selected Turkish news channels as their news sources of choice to a lesser extent than those in Belgium and Germany. When combined with our other findings that show the powerful effect that media use has on bridging and bonding, this difference in media use becomes an important finding, with implications for trajectories of integration.

Language becomes an important factor here, both shaping the entry to European or Turkish mainstream media. Language is also widely considered an important indicator of integration. Generally, people who speak the local language are more integrated, as our findings support. The differences we see in media use among the three countries may reflect their particular integration policies. 
We found that attitudes about integration policy vary widely by country with respondents in Belgium being much more satisfied with Belgium's integration policy than respondents in the Netherlands and Germany. Racist attitudes among native-born and experiences of discrimination seem to be the primary drivers of this variation by country, with respondents from Germany and the Netherlands reporting much higher incidences of racist attitudes and experiences of discrimination than those in Belgium. This suggests that the prevalence of racist attitudes towards the Turkish diaspora, or at least a public demonstration of such attitudes, is higher in Germany and the Netherlands compared to Belgium. Various factors undoubtedly account for the differing levels of discrimination within each country towards them.

Xenophobic attitudes in the host nation view Muslim communities as alien and a potential internal threat. This prejudiced perspective is responsible for a lack of acceptance of Muslims; its seemingly pervasive presence throughout Europe is a key factor in a negative cycle that feeds mistrust and antagonism (e.g., Moosavi, 2012). There is much to be gained by maintaining a dialogue between the majority and minority populations about religious and cultural practices that could increase mutual understanding.

The particularities of integration policy may be another factor shaping attitudes. Turkish migrants who wish to integrate to Germany are forced to relinquish their Turkish passport and renounce their citizenship. Prior to December of 2014, Turkish children born in Germany were asked to choose to be German or Turkish by the age of 23. After December of 2014, these children were no longer forced to choose their citizenship; but, they could not automatically remain a dual citizen and need to fulfil certain conditions (Conrad, 2014). Migrating to the Netherlands and Belgium is more lenient. Migrants who wish to be Dutch citizens do not automatically lose their native nationality, even though the Netherlands discourages dual citizenship (Pieters, 2017). Dual nationality is allowed in Belgium. 


\section{Future Directions}

This research produced a number of significant results, which also point to some avenues for future research. The most important of these is the necessity for a systematic method of quantifying the degree of integration and the effectiveness of integration policies, given that adopted policies vary widely by country. We also need to overcome the diversity of typologies and conceptualizations for integration. The lack of a unified or all-encompassing framework presents many challenges for those working in the field. Further, assessment of the quality of integration policies is still an ambiguous undertaking, as there is no clear sense of which policies are the most effective and beneficial for both immigrant and receiving populations. Similarly, many challenges remain to identifying and accessing an ideal subject group for this type of research.

The fieldwork performed for this research laid the groundwork for a larger study focused on the impact of the Gezi protest movement on the bridging and bonding of the Turkish diaspora and a network analysis of Twitter use by respondents and content analysis of users' tweets before, during and after the Gezi movement.

\section{Notes}

${ }^{1}$ The questionnaire can be found through the following link: https://instituteformediastudies.wordpress.com/2016/05/31/royaimanigiglou/

\section{Declaration of Conflicting Interests}

The author(s) declared no potential conflicts of interest with respect to the research, authorship, and/or publication of this article.

\section{Funding}

This research is funded by the KU Leuven Research Council. 


\section{References}

Aksoy A and Robins K (2000) Thinking across spaces: Transnational television from Turkey. European Journal of Cultural Studies 3(3): 343-365.

Amelina A and Faist T (2008) Turkish migrant associations in Germany: between integration pressure and transnational linkages. Revue européenne des migrations internationales 24(2): 91-120.

Baser B (2015) Diasporas and Homeland Conflicts: A Comparative Perspective. Ashgate Publishing.

Bozdağ Ç (2014) Policies of media and cultural integration in Germany: From guest worker programmes to a more integrative framework. Global Media and Communication 10(3): 289301.

Burt RS (2001) Structural holes versus network closure as social capital. In: Lin N, Cook KS and Burt RS (eds) Social Capital: Theory and Research. New York: Aldine de Gruyter, pp. $31-56$.

Castles S (1995) How nation states respond to immigration and ethnic diversity. Journal of Ethnic and Migration Studies 21(3): 293-308.

Christiansen CC (2004) News media consumption among immigrants in Europe: The relevance of diaspora. Ethnicities 4(2): 185-207.

Conrad, N (2014) Dual citizenship law takes effect in Germany. Accessed: 11/17 http://www.dw.com/en/dual-citizenship-law-takes-effect-in-germany/a-18143002

Council of Europe (1991) Recent Demographic Developments in Europe. Council of Europe Press, Strasbourg.

Crul M. and Schneider J (2010) Comparative integration context theory: Participation and belonging in new diverse European cities. Ethnic and Racial Studies 33(7): 1249-1268.

de Kool M (2015) Turkish Youths and Media Preferences: Researching the Media Behaviour of Third Generation Turkish-Dutch Immigrants in Rotterdam. Master Thesis. Erasmus School of History, Culture, \& Communication, Erasmus University. Rotterdam, The Netherlands.

d'Haenens L (2009) Whither cultural diversity on the Dutch TV screen?.In: Geissler R and Pöttker H (eds) Media, Migration, Integration: European and North American Perspectives, pp. 97-115. Bielefeld: Transcript.

Ersanilli E and Koopmans R (2011) Do immigrant integration policies matter? A threecountry comparison among Turkish immigrants. West European Politics 34(2): 208-234. 
Entzinger H (2014) The growing gap between facts and discourse on immigrant integration in the Netherlands. Identities 21(6): 693-707.

Fernández-Kelly MP (1995) Social and cultural capital in the urban ghetto: Implications of the economic sociology of immigration'. In: Portes A (ed) The Economic Sociology of Immigration. Essays on Networks, Ethnicity, and Entrepreneurship. New York: Russell Sage Foundation, pp. 214-247.

Flap H and Völker B (eds) (2010) Creation and Returns of Social Capital: A New Research Program. Oxon: Routledge.

Geddes A and Scholten P (2016) The Politics of Migration and Immigration in Europe. Thousand Oaks: Sage.

Georgiou M (2005) Diasporic media across Europe: Multicultural societies and the universalism-particularism continuum. Journal of Ethnic and Migration Studies 31(3): 481498.

Granovetter MS (1973) The strength of weak ties. American Journal of Sociology 78(6): 1360-1380.

Grieve R, Indian, M, Witteveen, K, Tolan, GA and Marrington J (2013) Face-to-face or Facebook: Can social connectedness be derived online? Computers in Human Behavior 29(3): 604-609.

Guiraudon V (2000) European integration and migration policy: Vertical policy- making as venue shopping. Journal of Common Market Studies 38(2): 251-271.

Huysmans J (2000) The European Union and the securitization of migration. Journal of Common Market Studies 38(5): 751-777.

Jacobs D (1999) The debate over enfranchisement of foreign residents in Belgium. Journal of Ethnic and Migration Studies 25(4): 649-664.

Jedwab J and Soroka S (2014) Indexing Integration: A Review Of National And International Models. Available at: https://acs-aec.ca/en/publications/ (accessed 26 November 2017).

Kaya A (2009) Islam, Migration and Integration: The Age of Securitization. London: Palgrave Macmillan.

Koopmans R (ed.) (2005) Contested Citizenship: Immigration and Cultural Diversity in Europe (Vol. 25). Minneapolis: University of Minnesota Press. 
Kymlicka W (1995) Multicultural Citizenship: A Liberal Theory of Minority Rights. Oxford: Clarendon Press.

Lahav G and Perliger A (2016) Immigrant integration, political radicalization and terrorism in Europe: Some preliminary insights from the early millennium (2000-2010).' In: Freeman GP and Mirilovic N (eds.) Handbook on Migration and Social Policy. Cheltenham, UK: Edward Elgar Publishing, pp. 265-289.

Lancee B (2010) The economic returns of immigrants' bonding and bridging social capital: The case of the Netherlands'. International Migration Review 44(1): 202-226.

Loch D (2014) Integration as a sociological concept and national model for immigrants: Scope and limits. Identities 21(6): 623-632.

Mattelart T and d'Haenens L (2014) Cultural diversity Ppolicies in Europe: Between integration and security. Global Media and Communication 10(3): 231-245.

McLaren LM. (2003) Anti-immigrant prejudice in Europe: Contact, threat perception, and preferences for the exclusion of migrants. Social Forces 81(3): 909-936.

Mittelstädt A and Odag Ö (2015) Social media use and social integration of ethnic minorities in Germany: A new interdisciplinary framework. Athens: ATINER's Conference Paper Series.

Moosavi L (2012, July 3) Muslims are well-integrated in Britain-but no one seems to believe it. The Guardian.

Ogan C and d'Haenens L (2012) Do Turkish women in the diaspora build social capital? Evidence from the Low Countries. Ethnic and Racial Studies 35(5): 924-940.

Ogan C, Giglou RI and d'Haenens L (2016) Challenges of conducting survey research related to a social protest movement: Lessons learned from a study of Gezi protests involving the Turkish diaspora in three European countries. The Information Society 33(1): 1-12.

Park N, Song H and Lee KM (2014) Social networking sites and other media use, acculturation stress, and psychological well-being among East Asian college students in the United States. Computers in Human Behavior 36: 138-146.

Peeters AL and d'Haenens L (2005) Bridging or bonding? Relationships between Integration and Media Use among Ethnic Minorities in the Netherlands. Communications 30(2): 201-231. 
Penninx R (2003, October 1) Integration: The role of communities, institutions and the State. Migration Information Source. Migration Policy Institute. Available at:

https://www.migrationpolicy.org/article/integration-role-communities-institutions-and-state (accessed 26 November 2017).

Pieters J (2017) Dutch MPS debate dual citizenship legality after Turkish referendum vote. Available at: 10/17 https://nltimes.nl/2017/04/19/dutch-mps-debate-dual-citizenshiplegality-turkish-referendum-vote (accessed 26 November 2017).

Putnam RD (2001) Bowling Alone: The Collapse and Revival of American Community. New York: Simon \& Schuster.

Republic of Turkey Ministry of Foreign Affairs (2017) Turkish Citizens Living Abroad. Available at: /http://www.mfa.gov.tr/the-expatriate-turkish-citizens.en.mfa (accessed 26 November 2017).

Robins K and Aksoy A (2015) Transnationalism, Migration and the Challenge to Europe: The Enlargement of Meaning. Oxon: Routledge.

Scholten P and Holzhacker R (2009) Bonding, bridging and ethnic minorities in the Netherlands: changing discourses in a changing nation. Nations and Nationalism 15(1): 81100 .

Stemmann JJE (2006) Middle East Salafism's influence and the radicalization of Muslim communities in Europe. The Middle East Review of International Affairs 10(3). Available at: http://www.publikationen.ub.uni-frankfurt.de/oai/container/index/docid/11917 (accessed 26 November 2017).

Wets J (2006) The Turkish community in Austria and Belgium: The challenge of integration. Turkish Studies 7(1): 85-100.

Wieviorka M (2014) A critique of integration. Identities 21(6): 633-641.

Woolcock M and Narayan D (2000) Social capital: Implications for development theory, research, and policy. The World Bank Research Observer 15(2): 225-249. 